\title{
Pre-operative nutritional status does not alter the metabolic response to major gastrointestinal surgery in patients with oesophageal cancer
}

\author{
Peter H. Bisschop ${ }^{1 *}$, Samuel Klein ${ }^{2}$, Mariëtte T. Ackermans ${ }^{3}$, Bruce W. Patterson ${ }^{2}$, Erik Endert ${ }^{3}$, \\ Jan J. B. van Lanschot ${ }^{4}$, Johannes A. Romijn ${ }^{5}$ and Hans P. Sauerwein ${ }^{1}$ \\ ${ }^{1}$ Department of Endocrinology and Metabolism (F5-165), Academic Medical Center, PO Box 22700, 1100 DE Amsterdam, \\ The Netherlands \\ ${ }^{2}$ Center for Human Nutrition, Washington University School of Medicine, Campus Box 8031, 660 South Euclid Avenue, St Louis, \\ MO 63110,USA \\ ${ }^{3}$ Department of Clinical Chemistry, Laboratory of Endocrinology and Radiochemistry, Academic Medical Center, PO Box 22700 , \\ 1100 DE Amsterdam, The Netherlands \\ ${ }^{4}$ Department of Surgery, Academic Medical Center, PO Box 22700, 1100 DE Amsterdam, The Netherlands \\ ${ }^{5}$ Department of Endocrinology, Leiden University Medical Center, Building 1, C4-R, PO Box 9600, 2300 RC Leiden, The \\ Netherlands
}

(Received 21 August 2006 - Revised 18 December 2006 - Accepted 12 January 2007)

\begin{abstract}
Malnutrition is associated with an increased incidence of perioperative morbidity and mortality. To evaluate the effect of malnutrition on the metabolic and inflammatory response to surgery in patients with oesophageal cancer, we studied the effects of oesophagectomy in six patients with major (13.9 (SE 1.3) \%) weight loss and five patients with minor (0.7 (SE 0.6) \%) weight loss in the 6 months before to surgery. Rates of appearance $\left(R_{\mathrm{a}}\right)$ of glucose, glycerol, leucine and urea were determined by stable isotopically labelled tracer infusion before and after surgery. C-reactive protein was measured as an inflammation marker. BMI was lower in the patients with major weight loss than those with minor weight loss $(20 \cdot 3$ (SE 0.7) and $24.9(\mathrm{SE} 1.5) \mathrm{kg} / \mathrm{m}^{2}, P=0.02$ ). With the exception of greater glucose $R_{\mathrm{a}}$ in the major weight loss than minor weight loss subjects $(11.1$ (SE 0.3) v. 9.5 (SE 0.3$) \mu \mathrm{mol} / \mathrm{kg}$ per min, $P=0.01$ ), there were no differences in substrate kinetics before surgery between groups. Surgery increased glucose $R_{\mathrm{a}}$, leucine $R_{\mathrm{a}}$ and urea $R_{\mathrm{a}}$ by 41,24 and $58 \%$, respectively, in the total group. Changes in substrate kinetics in response to surgery were not different between patients with major and minor weight loss. Surgery increased C-reactive protein concentrations to a comparable extent in both groups. In conclusion, major upper gastrointestinal tract surgery in patients with oesophageal cancer elicits a catabolic response, characterized by increased inflammation, glucose production and protein breakdown. However, this catabolic response does not seem to be influenced by pre-operative nutritional status.
\end{abstract}

Malnutrition: Surgery: Oesophageal neoplasm: Glucose production: Proteolysis

Pre-operative malnutrition, defined by percentage body weight loss, increases the risk of post-operative medical complications (Buzby et al. 1980; Warnold \& Lundholm, 1984; Klein et al. 1996; Studley, 2001). The mechanism(s) responsible for the relationship between malnutrition and an adverse clinical outcome is not clear, but could be related to physiological alterations induced by the combined metabolic stress of surgery and malnutrition. In patients with cancer, weight loss is caused by a combination of malnutrition due to reduced food intake and increased demands due to systemic or local inflammation. Patients with cancer of the upper gastrointestinal tract are particularly prone to developing malnutrition because of poor food intake caused by mechanical intestinal obstruction. A percentage (10-20\%) of patients with upper gastrointestinal tract cancer also have evidence of a systemic inflammatory response (Ikeda et al. 2003; Shimada et al. 2003). Moreover, surgical resection of upper gastrointestinal tract cancer is a major operative procedure, and represents a considerable stress to a patient who is already compromised by weight loss and muscle wasting.

The metabolic effects of upper gastrointestinal tract resection are not known, but are likely to be similar to the effects of tissue injury in general. Patients who have experienced physical trauma have increased rates of endogenous glucose production and lipolysis, and exhibit net protein catabolism (Shaw \& Wolfe, 1989). It is not known whether malnutrition modifies the metabolic response to major gastrointestinal surgery. Therefore, it is possible that malnutrition-induced

\footnotetext{
Abbreviation: $R_{\mathrm{a}}$, rate of appearance.

* Corresponding author: Dr Peter H. Bisschop, fax +31 20 6917682, email p.h.bisschop@amc.uva.nl
} 
alterations in the metabolic response to surgery increase the risk of post-operative complications.

The aim of the present study was to evaluate the effects of malnutrition on the metabolic response to oesophageal resection as a model of major gastrointestinal surgical intervention. Stable isotopically labelled tracer infusion was used to assess protein, glucose and lipid kinetics before and after surgery in patients with oesophageal carcinoma, who were judged to be malnourished or adequately nourished based on changes in pre-operative body weight.

\section{Subjects and methods}

\section{Subjects}

A total of eleven men and women with oesophageal cancer, who were admitted to the hospital for oesophagectomy, participated in the present study (Table 1). Patients with diabetes, severe organ disease or those taking medications that would affect substrate metabolism were excluded. All patients were deemed eligible for radical resection of the tumour and surrounding lymph nodes after radiographical evaluation of the disease state by computed tomography of the thorax and upper abdomen, ultrasound of the neck and endoesophageal ultrasonography. Subjects were divided into two groups, based on documented weight change over a period of 6 months before surgery: those who lost more than $10 \%$ of their initial, stable body weight were considered the major weight loss group and those who lost less than $5 \%$ body weight were considered the minor weight loss group. All subjects gave written, informed consent before their participation in the study, which was approved by the Medical Ethical Committee of the Academic Medical Center.

\section{Experimental protocol}

Subjects were admitted to the surgical ward of the Academic Medical Center $3 \mathrm{~d}$ before surgery. All subjects ate breakfast on the day of admission, but were only allowed to drink non-caloric beverages after the breakfast meal was consumed. A standard pre-operative bowel preparation protocol was initiated, which involved having the subjects drink a nonabsorbable electrolyte solution (Klean Prep; Helsinn Birex Pharmaceuticals Ltd, Dublin, Ireland), until adequate bowel cleansing was achieved, which was not later than 18.00 hours on the second day of admission.

The following morning, on the third day of admission ( 1 day before surgery), $\mathrm{V}_{\mathrm{O} 2}$ and $\mathrm{CO}_{2}$ production rates were determined by using a metabolic measurement cart with ventilated hood system (Sensormedics model 2900; Sensormedics, Anaheim, CA, USA), and an isotope infusion study to assess substrate kinetics was performed. At 07.00 hours subjects were transferred to the metabolic ward. Subjects were weighed, and body fat percentage was determined by bioimpedance analysis (Akern, Florence, Italy). All patients were clinically and biochemically euvolemic. A catheter for isotope tracer infusion was inserted in an antecubital vein. Another catheter was placed in a hand vein of the contralateral arm and used to sample arterialized blood by heating the hand to $60^{\circ} \mathrm{C}$ in a thermostatically controlled box. At 08.00 hours, after blood samples were obtained to determine background plasma substrate enrichments, primed, constant infusions of $\left[5,5,5-{ }^{2} \mathrm{H}_{3}\right] \mathrm{L}-$ leucine $(98 \%$ enriched; Cambridge Isotope Laboratories, Andover, MA, USA; $9 \mu \mathrm{mol} / \mathrm{kg}$ priming dose and $0.15 \mu \mathrm{mol} / \mathrm{kg}$ per min constant infusion) and $\left[{ }^{15} \mathrm{~N}_{2}\right]$ urea ( $>98 \%$ enriched; Cambridge Isotope Laboratories; $67.2 \mu \mathrm{mol} / \mathrm{kg}$ priming dose and $0.12 \mu \mathrm{mol} / \mathrm{kg}$ per min constant infusion) were started and continued for $8 \mathrm{~h}$. At 13.30 hours, a primed, constant infusion of $\left[6,6-{ }^{2} \mathrm{H}_{2}\right] \mathrm{D}$-glucose $(99 \%$ enriched; Cambridge Isotope Laboratories; $17.6 \mu \mathrm{mol} / \mathrm{kg}$ priming dose and $0 \cdot 22 \mu \mathrm{mol} / \mathrm{kg}$ per min constant infusion) was started and continued for $2.5 \mathrm{~h}$. At 14.30 hours, a primed, constant infusion of $\left[{ }^{2} \mathrm{H}_{5}\right]$ glycerol $(99 \%$ enriched; Cambridge Isotope Laboratories; $1.5 \mu \mathrm{mol} / \mathrm{kg}$ priming dose and $0 \cdot 10 \mu \mathrm{mol} / \mathrm{kg}$ per min constant infusion) was started and continued for $1.5 \mathrm{~h}$. Blood samples were obtained at $15.30,15.40,15.50$ and 16.00 hours to determine plasma enrichment of urea, leucine, glucose and glycerol. After the

Table 1. Patient characteristics

\begin{tabular}{|c|c|c|c|c|c|c|}
\hline Sex & $\begin{array}{c}\text { Age } \\
\text { (years) }\end{array}$ & $\begin{array}{c}\mathrm{BMl} \\
\left(\mathrm{kg} / \mathrm{m}^{2}\right)\end{array}$ & Fat (\%) & Lean body mass $(\mathrm{kg})$ & Weight change (\%) & $\begin{array}{c}\text { Carcinoma } \\
\text { (pTNM-stage and type) }\end{array}$ \\
\hline \multicolumn{7}{|c|}{ Minor weight loss } \\
\hline Male & 63 & $22 \cdot 3$ & $24 \cdot 5$ & $49 \cdot 8$ & 0.0 & $\mathrm{~T}_{1} \mathrm{~N}_{0} \mathrm{M}_{0}$, squamous cell \\
\hline Male & 71 & $20 \cdot 4$ & $19 \cdot 5$ & 47.5 & -3.4 & $\mathrm{~T}_{2} \mathrm{~N}_{1} \mathrm{M}_{0}$, squamous cell \\
\hline Male & 51 & $25 \cdot 9$ & $18 \cdot 7$ & $65 \cdot 9$ & 0.0 & $\mathrm{~T}_{3} \mathrm{~N}_{1} \mathrm{M}_{1}$, adenocarcinoma \\
\hline Female & 63 & $27 \cdot 9$ & $37 \cdot 2$ & $42 \cdot 1$ & $0 \cdot 0$ & In situ \\
\hline Female & 70 & $28 \cdot 1$ & 31.5 & 44.5 & 0.0 & $\mathrm{~T}_{1} \mathrm{~N}_{0} \mathrm{M}_{0}$, squamous cell \\
\hline Mean & 64 & $24 \cdot 9$ & $26 \cdot 3$ & $50 \cdot 0$ & -0.7 & \\
\hline SE & 4 & 1.5 & $3 \cdot 6$ & $4 \cdot 2$ & 0.6 & \\
\hline \multicolumn{7}{|c|}{ Major weight loss } \\
\hline Female & 67 & $20 \cdot 7$ & $27 \cdot 6$ & $41 \cdot 3$ & $-12 \cdot 3$ & $\mathrm{~T}_{1} \mathrm{~N}_{0} \mathrm{M}_{0}$, squamous cell \\
\hline Female & 65 & 21.4 & $22 \cdot 8$ & $41 \cdot 7$ & -14.3 & $\mathrm{~T}_{3} \mathrm{~N}_{1} \mathrm{M}_{1}$, squamous cel \\
\hline Male & 55 & $20 \cdot 7$ & $12 \cdot 0$ & $65 \cdot 1$ & $-13 \cdot 1$ & $\mathrm{~T}_{3} \mathrm{~N}_{1} \mathrm{M}_{0}$, squamous cell \\
\hline Female & 56 & $16 \cdot 9$ & $17 \cdot 2$ & 38.9 & $-13 \cdot 2$ & $\mathrm{~T}_{3} \mathrm{~N}_{0} \mathrm{M}_{0}$, squamous cell \\
\hline Male & 73 & $20 \cdot 0$ & $19 \cdot 0$ & $51 \cdot 8$ & $-20 \cdot 0$ & $\mathrm{~T}_{3} \mathrm{~N}_{1} \mathrm{M}_{0}$, adenocarcinoma \\
\hline Male & 74 & $22 \cdot 0$ & $29 \cdot 3$ & 49.5 & $-10 \cdot 4$ & $\mathrm{~T}_{3} \mathrm{~N}_{1} \mathrm{M}_{0}$, squamous cell \\
\hline Mean & 65 & $20 \cdot 3^{*}$ & $21 \cdot 3$ & $48 \cdot 1$ & $-13 \cdot 9^{\star \star}$ & \\
\hline SE & 3 & 0.7 & $2 \cdot 7$ & 4.0 & $1 \cdot 3$ & \\
\hline
\end{tabular}

Mean values were significantly different from those of the minor weight loss group: ${ }^{\star} P=0.017 ;{ }^{\star \star} P<0.001$. 
isotope infusion protocol was completed, subjects were transferred back to the surgical ward.

The following morning (the fourth day of admission), an oesophageal resection was performed in all subjects followed by gastric tube reconstruction. The transhiatal approach was used in four subjects in each of the two groups and the transthoracic approach was used in the remaining subjects. Blood loss during surgery was 1216 (SE 389) and 1517 (SE 472) $\mathrm{ml}$ in the minor and major weight loss groups, respectively (NS). Subjects were given intravenous normal saline after surgery, but did not receive parenteral or enteral calories until completion of the second isotope infusion study.

On the second post-operative day (the sixth day of admission), the same isotope infusion protocol as performed before surgery was repeated. Therefore, the first isotope infusion protocol was performed after approximately $2 \mathrm{~d}$ of fasting and the second isotope infusion protocol was performed after approximately $5 \mathrm{~d}$ of fasting. One subject in the minor weight loss group received norepinephrine infusion during the post-operative study, because of hypotension. An infectious cause was suspected and broadspectrum antibiotic therapy was initiated. Because all cultures remained negative the antibiotic therapy was discontinued on the fourth post-operative day. Norepinephrine dependency decreased gradually and norepinephrine administration was discontinued on the sixth postoperative day. Although all results include data from this subject, eliminating the data from this subject did not change the statistical significance of any end-points.

\section{Analytical procedures}

Plasma insulin concentration was determined by RIA (Insulin RIA 100; Pharmacia Diagnostic AB, Uppsala, Sweden): intraassay CV 3-5\%, inter-assay CV 6-9\%, detection limit $15 \mathrm{pmol} / \mathrm{l}$. Plasma C-peptide concentration was determined by RIA (RIA-coat c-peptide; Byk-Sangtec Diagnostica GmbH \& Co. KG, Dietzenbach, Germany): intra-assay CV 4-6\%, inter-assay CV 6-8\%, detection limit $50 \mathrm{pmol} / \mathrm{l}$. Cortisol concentration was measured by enzyme-immunoassay on an Immulite analyser (DPC, Los Angeles, CA, USA): intra-assay CV 2-4\%, inter-assay CV 3-7\%, detection limit $50 \mathrm{nmol} / 1$. Glucagon concentration was determined by RIA (Linco Research, St Charles, MO, USA): intra-assay CV 3-5\%, inter-assay CV $9-13 \%$, detection limit $15 \mathrm{ng} / \mathrm{l}$. Epinephrine concentrations were determined by an in-house HPLC method: intra-assay CV 6-8\%, inter-assay CV 7-12\%, detection limit $0.05 \mathrm{nmol} /$ 1. Serum NEFA were measured using an enzymatic method (NEFAC; Wako Chemicals GmbH, Neuss, Germany): intraassay CV 2-4\%, inter-assay CV 3-6\%, detection limit $0.02 \mathrm{mmol} / \mathrm{l}$. Plasma C-reactive protein was determined using a fully automated assay on a Hitachi 912 (Roche Diagnostics Netherlands BV, Almere, The Netherlands).

Plasma glucose enrichment was determined by deproteinizing plasma with methanol (Reinauer et al. 1990). The aldononitrile penta-acetate derivative of glucose (Knap, 1979) was injected into a Hewlett Packard 5973 GC/MS system (Hewlett Packard, Palo Alto, CA, USA). Separation was achieved on a J\&W DB17 column $\left(30 \mathrm{~m} \times 0.25 \mathrm{~mm}, d_{\mathrm{f}} 0.25 \mu \mathrm{m}\right)$. Glucose concentrations were determined by GC using xylose as an internal standard. Glucose was monitored at mass-to-charge ratio $(\mathrm{m} / \mathrm{z}) 187,188$ and 189 . The enrichment of $\left[6,6-{ }^{2} \mathrm{H}_{2}\right]$ glucose was determined by dividing the peak area of $\mathrm{m} / \mathrm{z} 189$ by the total peak area and correcting for natural enrichments.

The enrichment of $\left[1,1,2,3,3-{ }^{2} \mathrm{H}_{5}\right]$ glycerol in plasma was determined as described previously (Ackermans et al. 1998).

Plasma leucine, urea and $\alpha$-ketoisocaproate enrichments were determined after deproteinizing plasma with ice-cold acetone. tert-butyldimethylsilyl derivatives (Patterson et al. 1993) were injected into a Hewlett-Packard 5973 GC/MS system equipped with a HP-5MS column $(30 \mathrm{~m} \times 0.25 \mathrm{~mm})$. Leucine was monitored at $m / z, 200$ and 203, $\alpha$-ketoisocaproate was monitored at $\mathrm{m} / \mathrm{z}, 301$ and 304, and urea was monitored at $\mathrm{m} / \mathrm{z} 231$ and 233. Enrichments were determined by comparison of instrumental peak area ratios to standards of known isotopic enrichment.

\section{Calculations}

Physiological and isotopic steady states were present during the last $30 \mathrm{~min}$ of isotope infusion. Therefore, Steele's equation for steady-state conditions as adapted for the use of stable isotopes (Steele, 1959) was used to calculate wholebody leucine, urea, glucose and glycerol kinetics.

\section{Statistical analysis}

Data are presented as means and their standard errors. Student's $t$ test was used to test for pre-operative differences and for differences in the reponse to surgery between the minor and major weight loss group. Student's $t$ test for paired samples was used to test for differences between pre-operative and post-operative values within each group. A $P$ value of less than 0.05 was considered to be statistically different.

\section{Results}

\section{Post-operative complications}

In the minor weight loss group three patients had post-operative medical complications: one had rectal bleeding from a colonic diverticulum; one had leakage of the proximal anastomosis and developed a pneumonia with pleural empyema; one had a severe pseudomembranous colitis with sepsis and multiorgan failure for which a subtotal colectomy had to be performed.

In the major weight loss group three patients had post-operative medical complications: one had pleural empyema; one had a high production rate of the thoracic drain without evidence of infection or chylothorax and the production decreased spontaneously after several days; one patient had a cardiac arrest 1 week after surgery and died.

\section{Energy metabolism}

Pre-operatively, basal $\mathrm{V}_{\mathrm{O} 2}$ expressed per kg lean body mass was not different between subjects with minor weight loss (4.57 (SE 0.23) $\mathrm{ml} / \mathrm{kg}$ lean body mass per min) and those with major weight loss (5.14 (SE 0.23) $\mathrm{ml} / \mathrm{kg}$ lean body mass per min). In addition, RQ were not different between the minor and major weight loss groups $(0.70$ (SE 0.03) and 0.71 (SE 0.02), respectively), indicating that endogenous fat represented the major source of fuel in both groups. 
Table 2. Pre-operative and post-operative plasma hormone and C-reactive protein concentrations in patients with minor $(n 5)$ and major $(n 6)$ weight loss (Mean values with their standard errors)

\begin{tabular}{|c|c|c|c|c|c|c|c|}
\hline & & \multicolumn{2}{|c|}{ Minor weight loss } & \multicolumn{2}{|c|}{ Major weight loss } & \multicolumn{2}{|c|}{$\begin{array}{l}\text { Major and minor } \\
\text { weight loss }\end{array}$} \\
\hline & & Mean & SE & Mean & SE & Mean & SE \\
\hline \multirow{2}{*}{ Insulin (pmol/l) } & Pre-operative & 36 & 7 & 23 & 3 & 29 & 4 \\
\hline & Post-operative & 67 & 23 & 26 & 3 & 45 & 12 \\
\hline \multirow[t]{2}{*}{ Glucagon (ng/l) } & Pre-operative & 78 & 12 & 64 & 13 & 70 & 9 \\
\hline & Post-operative & 192 & 56 & 74 & 12 & 128 & 31 \\
\hline \multirow[t]{2}{*}{ Cortisol (nmol/l) } & Pre-operative & 287 & 47 & 399 & 46 & 348 & 36 \\
\hline & Post-operative & 606 & 118 & 572 & 78 & $587^{*}$ & 65 \\
\hline \multirow[t]{2}{*}{ Epinephrine (nmol/l) } & Pre-operative & 0.54 & 0.17 & 0.45 & 0.13 & 0.49 & $0 \cdot 10$ \\
\hline & Post-operative & 0.67 & $0 \cdot 10$ & 0.47 & $0 \cdot 10$ & 0.56 & 0.07 \\
\hline \multirow[t]{2}{*}{ C-reactive protein (mg/l) } & Pre-operative & 5 & 1 & 9 & 4 & 8 & 2 \\
\hline & Post-operative & $225^{\star}$ & 24 & $190^{*}$ & 19 & $206^{*}$ & 15 \\
\hline
\end{tabular}

Mean values were significantly different from those of the pre-operative group: ${ }^{\star} P<0.05$.

\section{Plasma hormone, cytokine and acute phase protein} concentrations

Plasma hormone and C-reactive protein concentrations before and after surgery are shown in Table 2. Surgery increased C-reactive protein levels in all subjects, but the increase was not different between the minor and major weight loss group. Pre-operative hormone concentrations were not different between the groups nor were they significantly altered by surgery.

\section{Glucose metabolism}

Pre-operative basal plasma glucose concentrations were not different between the minor and major weight loss groups (4.87 (SE 0.30) and 4.39 (SE 0.39) mmol/l, respectively), but the pre-operative rate of endogenous glucose production was greater in patients with major than minor weight loss (Table 3). Surgery increased glucose production in both the minor and major weight loss groups by approximately $40 \%$.

\section{Lipid metabolism}

Basal plasma NEFA concentrations were not different between subjects with minor and major weight loss before (1.04 (SE 0.14$)$ and $1.15(\mathrm{SE} 0.15) \mathrm{mmol} / \mathrm{l}$, respectively) or after (0.65 (SE 0.09) and 0.74 (SE 0.04) mmol/1, respectively) surgery. In accordance with plasma NEFA concentrations, whole-body lipolytic rate, as estimated by glycerol rate of appearance $\left(R_{\mathrm{a}}\right)$, was not different between groups before or after surgery (Table 3 ).

\section{Protein metabolism}

Leucine $R_{\mathrm{a}}$, an index of whole-body protein breakdown, was not different between patients with minor and major weight loss before surgery (Table 3). Surgery increased leucine $R_{a}$ in patients with minor $(\sim 23 \%, P=0.07)$ and major $(\sim 25 \%$, $P=0.03)$ weight loss, but the increase was significant only in the major weight loss group. Urea $R_{\mathrm{a}}$ was not different between groups before or after surgery (Table 3 ).

Table 3. Pre-operative and post-operative rate of appearance $\left(R_{\mathrm{a}}\right)$ of glucose, glycerol, leucine and urea in patients with minor $(n 5)$ and major $(n 6)$ weight loss

(Mean values with their standard errors)

\begin{tabular}{|c|c|c|c|c|c|c|c|}
\hline & & \multicolumn{2}{|c|}{ Minor weight loss } & \multicolumn{2}{|c|}{ Major weight loss } & \multicolumn{2}{|c|}{$\begin{array}{l}\text { Major and minor } \\
\text { weight loss }\end{array}$} \\
\hline & & Mean & SE & Mean & SE & Mean & SE \\
\hline \multirow[t]{3}{*}{ Glucose ( $\mu \mathrm{mol} / \mathrm{kg}$ per $\min )$} & Pre-operative & $9 \cdot 51$ & 0.34 & $11 \cdot 05^{\star}$ & 0.32 & $10 \cdot 44$ & 0.34 \\
\hline & Post-operative & 13.44 & 1.49 & $15 \cdot 27 \dagger$ & 0.79 & $14.54 †$ & 0.77 \\
\hline & $\%$ Change & 43 & 20 & 40 & 10 & 41 & 9 \\
\hline \multirow[t]{3}{*}{ Glycerol ( $\mu \mathrm{mol} / \mathrm{kg}$ per min) } & Pre-operative & 3.62 & 0.40 & $4 \cdot 18$ & 0.36 & 3.96 & 0.27 \\
\hline & Post-operative & 3.35 & 0.40 & 3.57 & 0.33 & 3.48 & 0.24 \\
\hline & $\%$ Change & 0 & 22 & -9 & 14 & -6 & 12 \\
\hline \multirow[t]{3}{*}{ Leucine ( $\mu \mathrm{mol} / \mathrm{kg}$ per min) } & Pre-operative & $1 \cdot 30$ & 0.15 & 1.46 & 0.08 & 1.39 & 0.08 \\
\hline & Post-operative & 1.55 & 0.07 & $1.79 \dagger$ & 0.07 & $1.68 \dagger$ & 0.06 \\
\hline & $\%$ Change & 23 & 9 & 25 & 8 & 24 & 6 \\
\hline \multirow[t]{3}{*}{ Urea ( $\mu \mathrm{mol} / \mathrm{kg}$ per min) } & Pre-operative & $2 \cdot 88$ & 0.55 & $3 \cdot 26$ & 0.37 & 3.08 & 0.31 \\
\hline & Post-operative & $3 \cdot 80$ & 0.49 & $4 \cdot 69$ & 0.52 & 4.29† & 0.37 \\
\hline & $\%$ Change & 57 & 43 & 59 & 31 & 58 & 24 \\
\hline
\end{tabular}

Mean values were significantly different from those of the minor and major weight loss group (tested only for pre-operative and $\%$ change): ${ }^{\star} P<0 \cdot 05$.

Mean values were significantly different from those of the pre-operative group: $\dagger P<0.05$ 


\section{Discussion}

The objective of the present study was to evaluate the effect of nutritional status on the metabolic response to major surgery. Therefore, we assessed serum markers of inflammation and substrate metabolism before and after oesophagectomy in patients with oesophageal cancer, who had either lost more than $10 \%$ or less than $5 \%$ of their initial body weight. Major weight loss was associated with a higher rate of glucose production before surgery, whereas fat and protein kinetics were not different between the two groups. Surgery caused a similar increase in glucose $R_{\mathrm{a}}(\sim 40 \%)$ and leucine $R_{\mathrm{a}}$ $(\sim 25 \%)$ in patients with major and minor weight loss. The present data indicate that pre-operative malnutrition does not seem to affect the metabolic response to major surgery in patients with oesophageal cancer.

We specifically selected two groups of patients with oesophageal cancer, who had marked differences in their nutritional status, based on recent changes in body weight. A weight loss of $10 \%$ or more within 6 months before surgery in patients with upper gastrointestinal tract cancers has been consistently associated with an increase in major post-operative complications (Bokhorst-de van der Schueren et al. 1997). Therefore, we specifically selected patients in whom we were able to document at least a $10 \%$ weight loss in the 6 months before surgery, and compared these patients with those who had experienced minor $(<5 \%)$ weight loss. These inclusion criteria resulted in marked differences in BMI between the two groups. Power analysis indicated that the sample size was sufficient to detect a 14, 29, 40 and $68 \%$ difference between groups for glucose, leucine, glycerol and urea $R_{\mathrm{a}}$, respectively, with a CI of 0.95 and a power of 0.8. Smaller differences may exist, but are below the detection limit of the present study. Due to a wide range in the hormonal response to surgery, the power to detect differences between groups (CI of 0.95) was low: 0.34, 0.32, 0.54 and 0.17 for insulin, glucagon, cortisol and epinephrine, respectively.

The subjects were studied during fasting conditions at the time of both metabolic studies. The protocol for oesophageal resection included bowel cleansing, which was initiated $3 \mathrm{~d}$ before surgery, and subjects were not fed for $2 \mathrm{~d}$ after surgery. As a result, the subjects had been fasting for $2 \mathrm{~d}$ at the time of the pre-operative study and for $5 \mathrm{~d}$ at the time of the postoperative study. The effects of prolonged fasting on glucose, fat and protein metabolism have been well characterized in healthy subjects. Glucose production decreases gradually between 18 and $54 \mathrm{~h}$ of fasting from approximately $11.0 \mu \mathrm{mol} / \mathrm{kg}$ per min to a stable rate of $\sim 8.3 \mu \mathrm{mol} / \mathrm{kg}$ per min (Nair et al. 1987; Klein et al. 1993). Glycerol $R_{\mathrm{a}}$ increases in response to fasting, but more than half of the total increase during a $72 \mathrm{~h}$ fast occurs between 12 and $24 \mathrm{~h}$ of fasting. The increase in glycerol $R_{\mathrm{a}}$ between 24 and $72 \mathrm{~h}$ of fasting is small, and reaches a plateau at $54 \mathrm{~h}$ of fasting of about $4 \mu \mathrm{mol} / \mathrm{kg}$ per min. Changes in protein metabolism in response to starvation reach a steady state after $3 \mathrm{~d}$ (Goschke et al. 1975; Forbes \& Drenick, 1979). Therefore, most of the metabolic adaptation to starvation occurs within $48 \mathrm{~h}$ of fasting, with relatively small changes in glucose, protein and fatty acid metabolism thereafter. Because our subjects were studied before surgery after about $48 \mathrm{~h}$ of fasting, the metabolic alterations observed at the time of the second isotope infusion study, which was conducted after an additional $72 \mathrm{~h}$ of fasting, are likely to primarily represent the effect of surgical stress rather than prolonged starvation. However, the pronounced effect of prolonged fasting on glucose, fat and protein metabolism may have obscured a potential effect of nutritional status. Cancer is often associated with progressive weight loss and cachexia induced by a combination of insufficient energy intake due to anorexia and catabolism induced by a complex interaction of inflammatory, endocrine and neural factors (Holroyde \& Reichard, 1986). Together these factors induce marked changes in glucose, protein and fat metabolism. Normally, endogenous glucose production rates decrease with energy restriction; glucose $R_{\mathrm{a}}$ decreases in lean subjects who have lost weight rapidly during short-term fasting (Klein et al. 1993) and in obese subjects who have lost weight more slowly by dieting (Vazquez \& Kazi, 1994). In contrast, glucose $R_{\mathrm{a}}$ was greater in the oesophageal cancer patients in the present study who had experienced major weight loss than in those who had minor weight loss. Increased glucose production rates have also been observed in patients with other types of cancer who have had weight loss (Holroyde et al. 1984; Heber et al. 1985; Cersosimo et al. 1991). In addition, we found that surgery caused an increase in glucose production, which is a known response to trauma (Jeevanandam et al. 1990; Mizock, 1995; Nygren et al. 1997), in patients who had major or minor weight loss before surgery. The clinical implications of increased glucose production in patients with weight loss and cancer are not known. Catabolic conditions in otherwise healthy subjects decrease glucose production. Therefore one might assume that weight loss in patients with oesophageal cancer is associated with increased glucose production via systemic effects of cancer, possibly by inflammatory or humoral factors. Although speculative, increased glucose production could prove to be an unfavourable prognostic factor analogous to C-reactive protein, a marker of systemic inflammation (Shimada et al. 2003).

In a previous study, conducted in patients with oesophageal cancer, whole-body lipolytic rate, measured after a $14 \mathrm{~h}$ fast, was 1.5 -fold greater in patients who had more than $10 \%$ weight loss than in patients without weight loss (Klein \& Wolfe, 1990). In the present study, whole-body lipolytic rate was not different between patients who had major or minor weight loss. This discrepancy between studies is probably due to differences in the duration of fasting. In the present study, whole-body lipolytic rate was measured after a much longer period of fasting $(48 \mathrm{~h})$ than in the previous study (14 h), which likely attenuated differences in lipolysis between the two groups. In healthy volunteers, whole-body lipolytic rate is 2 -fold greater after $48 \mathrm{~h}$ of fasting than after an overnight (12 h) fast (Klein et al. 1993).

Data from previous studies have shown that leucine $R_{\mathrm{a}}$ is not primarily affected by cancer (Borzotta et al. 1987; Harrison et al. 1989b). In the present study, pre-operative proteolysis, measured by the $R_{\mathrm{a}}$ of leucine in plasma, was not different between subjects with major and minor weight loss, which is consistent with observations obtained in subjects who have lost weight due to non-neoplastic gastrointestinal disease (Carbonnel et al. 1995). Therefore, protein metabolism is relatively well maintained in (pre-operative) cancer patients, even after significant weight loss. The post-operative $R_{\mathrm{a}}$ of leucine was increased irrespective of nutritional status in 
line with a previous report on cancer patients. The increased release of leucine was not associated with net protein loss, since urea production was constant. This implies that leucine incorporation into protein, although not measured directly, was increased as well and suggests that protein turnover is accelerated by surgical stress, which is compatible with a previous report on surgery in cancer patients (Harrison et al. 1989a).

In conclusion, major upper gastrointestinal surgery in patients with oesophageal cancer elicits a catabolic response that is characterized by increased glucose production and accelerated protein breakdown. Pre-operative malnutrition does not seem to alter the metabolic response to surgery in these patients.

\section{Acknowledgements}

This study was supported by National Institutes of Health grants DK 37948 and DK 56341 (Clinical Nutrition Research Unit).

\section{References}

Ackermans MT, Ruiter AF \& Endert E (1998) Determination of glycerol concentrations and glycerol isotopic enrichments in human plasma by gas chromatography/mass spectrometry. Anal Biochem 258, 80-86.

Bokhorst-de van der Schueren MA, van Leeuwen PA, Sauerwein HP, Kuik DJ, Snow GB \& Quak JJ (1997) Assessment of malnutrition parameters in head and neck cancer and their relation to postoperative complications. Head Neck 19, 419-425.

Borzotta AP, Clague MB \& Johnston ID (1987) The effects of gastrointestinal malignancy on whole body protein metabolism. J Surg Res 43, 505-512.

Buzby GP, Mullen JL, Matthews DC, Hobbs CL \& Rosato EF (1980) Prognostic nutritional index in gastrointestinal surgery. Am J Surg 139, 160-167.

Carbonnel F, Messing B, Darmaun D, Rimbert A, Rongier M, Rigal O, Koziet J, Thuillier F \& Desjeux JF (1995) Energy and protein metabolism in malnutrition due to nonneoplastic gastrointestinal diseases. Metabolism 44, 1110-1115.

Cersosimo E, Pisters PW, Pesola G, Rogatko A, Vydelingum NA, Bajorunas D \& Brennan MF (1991) The effect of graded doses of insulin on peripheral glucose uptake and lactate release in cancer cachexia. Surgery 109, 459-467.

Forbes GB \& Drenick EJ (1979) Loss of body nitrogen on fasting. Am J Clin Nutr 32, 1570-1574.

Goschke H, Stahl M \& Tholen H (1975) Nitrogen loss in normal and obese subjects during total fast. Klin Wochenschr 53, 605-610.

Harrison RA, Lewin MR, Halliday D \& Clark CG (1989a) Leucine kinetics in surgical patients. I: A study of the effect of surgical 'stress'. Br J Surg 76, 505-508.

Harrison RA, Lewin MR, Halliday D \& Clark CG (1989b) Leucine kinetics in surgical patients. II: A study of the effect of malignant disease and tumour burden. Br J Surg 76, 509-511.

Heber D, Byerly LO \& Chlebowski RT (1985) Metabolic abnormalities in the cancer patient. Cancer 55, 225-229.
Holroyde CP \& Reichard GA Jr (1986) General metabolic abnormalities in cancer patients: anorexia and cachexia. Surg Clin North Am 66, 947-956.

Holroyde CP, Skutches CL, Boden G \& Reichard GA (1984) Glucose metabolism in cachectic patients with colorectal cancer. Cancer Res 44, 5910-5913.

Ikeda M, Natsugoe S, Ueno S, Baba M \& Aikou T (2003) Significant host- and tumor-related factors for predicting prognosis in patients with esophageal carcinoma. Ann Surg 238, 197-202.

Jeevanandam M, Young DH \& Schiller WR (1990) Glucose turnover, oxidation, and indices of recycling in severely traumatized patients. J Trauma 30, 582-589.

Klein JD, Hey LA, Yu CS, Klein BB, Coufal FJ, Young EP, Marshall LF \& Garfin SR (1996) Perioperative nutrition and postoperative complications in patients undergoing spinal surgery. Spine 21, 2676-2682.

Klein S, Sakurai Y, Romijn JA \& Carroll RM (1993) Progressive alterations in lipid and glucose metabolism during short-term fasting in young adult men. Am J Physiol 265, E801-E806.

Klein S \& Wolfe RR (1990) Whole-body lipolysis and triglyceridefatty acid cycling in cachectic patients with esophageal cancer. J Clin Invest 86, 1403-1408.

Knap DR (1979) Handbook of Analytical Derivatization Reactions. Wiley-Interscience: New York, USA.

Mizock BA (1995) Alterations in carbohydrate metabolism during stress: a review of the literature. Am J Med 98, 75-84.

Nair KS, Woolf PD, Welle SL \& Matthews DE (1987) Leucine, glucose, and energy metabolism after 3 days of fasting in healthy human subjects. Am J Clin Nutr 46, 557-562.

Nygren J, Thorell A, Efendic S, Nair KS \& Ljungqvist O (1997) Site of insulin resistance after surgery: the contribution of hypocaloric nutrition and bed rest. Clin Sci (Colch) 93, 137-146.

Patterson BW, Carraro F \& Wolfe RR (1993) Measurement of ${ }^{15} \mathrm{~N}$ enrichment in multiple amino acids and urea in a single analysis by gas chromatography/mass spectrometry. Biol Mass Spectrom 22, 518-523.

Reinauer H, Gries FA, Hubinger A, Knode O, Severing K \& Susanto F (1990) Determination of glucose turnover and glucose oxidation rates in man with stable isotope tracers. J Clin Chem Clin Biochem 28, 505-511.

Shaw JH \& Wolfe RR (1989) An integrated analysis of glucose, fat, and protein metabolism in severely traumatized patients. Studies in the basal state and the response to total parenteral nutrition. Ann Surg 209, 63-72.

Shimada H, Nabeya Y, Okazumi S, et al. (2003) Elevation of preoperative serum C-reactive protein level is related to poor prognosis in esophageal squamous cell carcinoma. J Surg Oncol 83, $248-252$.

Steele R (1959) Influences of glucose loading and of injected insulin on hepatic glucose output. Ann N Y Acad Sci 82, 420-430.

Studley HO (2001) Percentage of weight loss: a basic indicator of surgical risk in patients with chronic peptic ulcer. 1936. Nutr Hosp 16, $141-143$.

Vazquez JA \& Kazi U (1994) Lipolysis and gluconeogenesis from glycerol during weight reduction with very-low-calorie diets. Metabolism 43, 1293-1299.

Warnold I \& Lundholm K (1984) Clinical significance of preoperative nutritional status in 215 noncancer patients. Ann Surg 199, 299-305. 